\title{
PERANCANGAN PENYEARAH SATU FASE TERKONTROL PENUH SEBAGAI CATU DAYA MOTOR ARUS SEARAH PADA PROTOTYPE OVERHEAD CRANE MODE HOISTING
}

\author{
Ariangga Bagas Wibisono*), Tejo Sukmadi, dan Mochammad Facta \\ Departemen Teknik Elektro, Universitas Diponegoro \\ J1. Prof. Sudharto, SH, Kampus UNDIP Tembalang, Semarang 50275, Indonesia \\ *E-mail : arianggabw@gmail.com
}

\begin{abstract}
Abstrak
Perkembangan industri dewasa ini meningkat seiring dengan meningkatnya kebutuhan manusia. Untuk memindahkan produk atau barang, diperlukan sebuah alat pemindah atau yang biasa disebut crane. Motor arus searah merupakan salah satu jenis motor yang digunakan sebagai penggerak crane. Pada saat ini, masih banyak pengaturan motor arus searah menggunakan kendali konvensional dengan proses penyearahan menggunakan transformator. Metode konvensional ini berupa tegangan yang tetap, sehingga tidak memiliki pilihan pengaturan tegangan dan keberadaan transformator membuat dimensinya besar dan harganya mahal. Dalam penelitian, penggunaan penyearah satu fase terkontrol penuh dengan IC TCA 785 sebagai pengatur sudut pemicu thyristor dirancang untuk mengatasi masalah tersebut. Konverter ini dirancang untuk menggerakkan motor CSD80A1-A sebagai bagian pada Prototype Overhead Crane mode hoisting. Penyearah satu fase terkontrol penuh bekerja dengan baik untuk memberikan suplai pada beban R dan R-L serta dapat menggerakan motor CSD80A1-A. Berdasarkan hasil percobaan, motor arus searah mampu menghasilkan kecepatan $41 \mathrm{rpm}$ hingga 141 rpm dengan uji pembebanan $0 \mathrm{~kg}$ hingga $13 \mathrm{~kg}$. Semakin besar sudut pemicuan yang diberikan oleh IC TCA 785, maka nilai tegangan dan arus keluaran akan semakin kecil. Nilai efisiensi dari penyearah satu fase terkontrol penuh ini mencapai $94 \%$.
\end{abstract}

Kata kunci : penyearah terkontrol satu fase, IC TCA 785, zero crossing detector, overhead crane, motor arus searah.

\begin{abstract}
Development of the industry today is increasing as the human needs is also increased. To move the product or goods, a lifting tools or commonly called a crane is needed. The direct current motor is a type of motor used as a crane drives. Recently, there are many direct current motor drives that use conventional control by using transformer rectification process. This classic method only give a fixed voltage, it does not have more voltage regulation choice and the transformer dimension is large and the price is expensive. In this work, the use of single phase fully controlled rectifier with IC TCA 785 as a thyristor trigger angle controller is designed to solve the problem. The converter is designed to drive the CSD80A1-A motor as a part of Prototype Overhead Crane hoisting mode. The single phase fully controlled rectifier works well for supplying R and R-L load variation and drives the CSD80A1-A motor. Based on test results, the direct current motor is able to rotate at speed $41 \mathrm{rpm}$ up to $141 \mathrm{rpm}$ with loading test $0 \mathrm{~kg}$ up to $13 \mathrm{~kg}$. the greater trigger angle given by IC TCA 785, the value of output voltage and current will be smaller. The efficiency of this fully controlled single phase rectifier has reached $94 \%$.
\end{abstract}

Keywords: single phase controlled rectifier, IC TCA 785, zero crossing detector, overhead crane, direct current motor.

\section{Pendahuluan}

Pertumbuhan dan perkembangan industri dewasa ini meningkat seiring dengan meningkatnya kebutuhan manusia. Untuk menyeimbangkan produksi yang dihasilkan yang sesuai dengan permintaan konsumen maka pihak industri dituntut untuk meningkatkan hasil produksi serta untuk memperlancar pendistribusian produknya. Didalam pendistribusian produk yang berkapasitas besar diperlukan sebuah alat pemindah yang biasa disebut crane untuk memperlancar kegiatan produksi disuatu industri yang sangat tidak mungkin diangkat oleh manusia[1].

Motor arus searah merupakan salah satu jenis motor listrik. Motor ini merupakan mesin listrik yang mengubah energi listrik arus searah menjadi energi mekanis. Motor arus searah sering digunakan di bidang industri seperti crane, conveyor, dan lift. Motor arus searah memiliki keunggulan yaitu torsi awal yang besar dan metode pengontrolan putarannya sederhana[2]. Metode yang 
digunakan pada pengontrolan kecepatan motor arus searah adalah dengan mengatur tegangan jangkar[3].

Pada saat ini masih banyak pengaturan motor arus searah menggunakan kendali konvensional dengan proses penyearahan menggunakan transformator. Metode konvensional ini berupa tegangan yang tetap, sehingga tidak memiliki banyak pilihan pengaturan tegangan dan transformator memiliki dimensi yang besar serta mahal dalam perawatan maupun perbaikanya. Salah satu metode alternatif yang dapat digunakan sebagai pengontrolan motor arus searah adalah dengan menggunakan rangkaian elektronika daya seperti rangkaian penyearah. Dari segi pengendaliannya, penyearah terbagi menjadi penyearah terkontrol dan tak terkontrol. Penyearah terkontrol merupakan rangkaian yang menggunakan thyristor (SCR) sebagai komponen penyearah yang dapat mengendalikan tegangan keluaran DC (direct current). Salah satu keuntungan dari thyristor adalah mampu mengalirkan daya besar dengan sinyal pemicuan kecil (miliwatt)[4].

Perancangan Tugas Akhir ini menggunakan IC TCA 785 sebagai sinyal pemicuan pada penyearah satu fase terkontrol penuh karena memiliki fitur zero crossing detector. Pemicuan yang diberikan memerlukan zero crossing detector agar pemicuan yang diberikan bisa sefase dengan sumbernya[5].

Tegangan keluaran dari penyearah satu fase terkontrol penuh ini digunakan sebagai catu daya sekaligus pengatur kecepatan motor arus searah sebagai penggerak mode hoisting pada Prototype Overhead Crane sebagai plant yang akan dikontrol. Pengaturan kecepatan motor arus searah dilakukan dengan mengatur sudut pemicuan thyristor (SCR) sampai batas nominal yang dikehendaki.

\section{Metode}

Gambar 1 menunjukan blok diagaram perancangan perangkat keras.

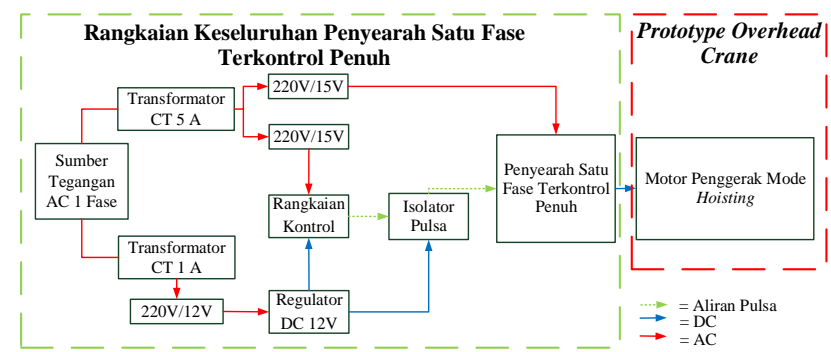

Gambar 1. Blok diagram perancangan

Blok diagram perancangan perangkat keras terbagi menjadi 2 blok yaitu, blok rangkaian keseluruhan penyearah satu terkontrol penuh dan blok Prototype Overhead Crane. Sumber tegangan AC satu fase menjadi sumber utama pada rangkaian. Transformator CT 1A digunakan untuk menurunkan tegangan dari 220 volt ke 12 $\mathrm{V}$ sebagai sumber regulator arus searah $12 \mathrm{~V}$. Transformator CT 5A digunakan untuk menurunkan tegangan dari $220 \mathrm{~V}$ ke $15 \mathrm{~V}$ sebagai sumber rangkaian penyearah satu fase terkontrol penuh dan sebagai referensi tegangan sinkronisasi IC TCA 785. Terdapat 3 jenis aliran arus pada perancangan perangkat keras ini yaitu aliran arus bolak-balik, searah, dan pulsa dengan arah yang sudah tertera pada Gambar 1. Penyearah satu fase terkontrol penuh akan memberikan catu daya ke motor arus searah sebagai penggerak Prototype Overhead Crane pada mode hoisting (pengangkat).

\subsection{Perancangan Sumber Tegangan Searah 12 Volt}

Perancangan penyearah gelombang penuh satu fase dengan center tap ini digunakan sebagai sumber tegangan rangkaian kontrol IC TCA 785 dan rangkaian isolator pulsa $4 \mathrm{~N} 35$.

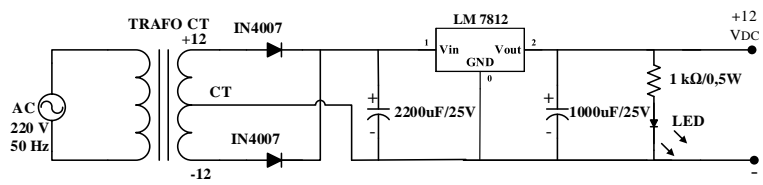

Gambar 2. Penyearah gelombang penuh satu fase dengan center tap

Topologi penyearah dengan trafo CT (center tap) dipilih karena hanya memerlukan 2 buah dioda untuk menghasilkan gelombang keluaran penyearah gelombang penuh. Kapasitor digunakan sebagai tapis tegangan untuk mengurangi ripple tegangan pada keluaran dioda.

\subsection{Rangkaian Kontrol IC TCA 785}

Rangkaian kontrol untuk penyearah satu fase jembatan terkontrol penuh dibuat dengan menggunakan 1 buah IC pengendali fase TCA785. Gambar 3. adalah rangkaian kontrol keseluruhan IC TCA 785.

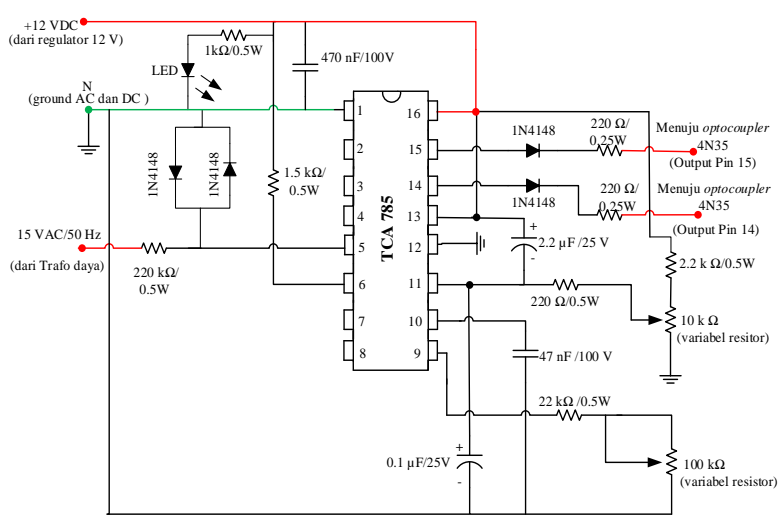

Gambar 3. Rangkaian kontrol IC TCA 785[5] 
IC TCA 785 menghasilkan dua sinyal pemicuan dari pin 14 dan pin 15 yang digunakan untuk mengendalikan pergeseran fase tegangan. Pada Gambar 4. memperlihatkan terdapat 2 masukan tegangan yang diberikan pada IC TCA 785 yaitu tegangan $12 \mathrm{~V}_{\mathrm{DC}}$ dan $15 \mathrm{~V}_{\mathrm{AC}}$. Tegangan $12 \mathrm{~V}_{\mathrm{DC}}$ merupakan catu daya IC TCA 785 sedangkan tegangan 15 $\mathrm{V}_{\mathrm{AC}}$ merupakan tegangan sinkronisasi antara rangkaian daya dengan rangkaian kontrol. Untuk melakukan pengontrolan sudut fase dilakukan dengan memutar resistor variabel yang terhubung pada pin 11 IC TCA 785[6]. Resistor variabel yang digunakan adalah resistor variabel bernilai $10 \mathrm{k} \Omega$.

\subsection{Rangkaian Isolator Pulsa 4N35}

Isolator pulsa digunakan sebagai driver untuk pemicuan thyristor (SCR). Selain itu isolator pulsa juga digunakan untuk mengisolasi antara rangkaian kontrol dengan rangkaian daya sehingga apabila terjadi gangguan pada rangkaian daya gangguan tersebut tidak merusak rangkaian kontrol. Pada perancangan Tugas Akhir ini akan digunakan isolator pulsa optocoupler 4N35. Optocoupler 4N35 nantinya akan menyalurkan tegangan pemicuan dari rangkaian kontrol menuju gate-cathode SCR, maka dari itu diperlukan 4 buah optocoupler 4N35 untuk menyulut masing-masing SCR. Rangkaian isolator pulsa 4N35 dapat dengan cepat memberikan arus dan membuang arus pada saat peralihan logika high dan low[7]. Gambar 4. akan menunjukan rangkaian isolator pulsa $4 \mathrm{~N} 35$.

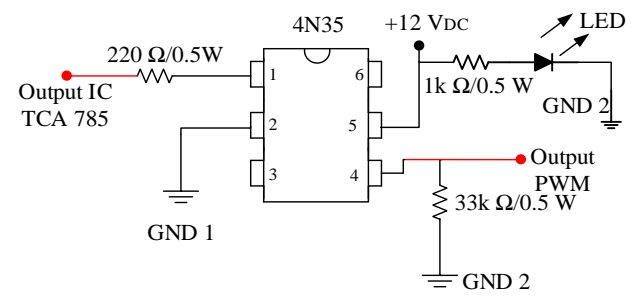

Gambar 4. Rangkaian isolator pulsa 4N35[8]

Gambar 4. Memperlihatkan terdapat catu daya yang akan digunakan untuk isolator pulsa 4 N35 bernilai 12 volt. Catu daya akan dibuat sebanyak 4 buah untuk masing-masing isolator pulsa $4 \mathrm{~N} 35$ karena masing-masing SCR memerlukan titik netral yang berbeda agar jika terdapat SCR mengalami kerusakan maka tidak merusak SCR lainya.

\subsection{Perancangan Rangkaian Penyearah Satu Fase Jembatan Terkontrol Penuh}

Penyerah satu fase jembatan terkontrol penuh digunakan sebagai catu daya DC sekaligus pegendali kecepatan untuk motor arus searah pada Prototype Overhead Crane mode hoisting. Pada perancangan penyearah satu fase jembatan terkontrol penuh akan digunakan SCR tipe BT151-600R. Untuk mengaktifkan rangkaian penyearah, pada SCR perlu diberikan pemicuan berupa tegangan positif diantara terminal gate dan katoda. Pemicuan harus diberikan pada satu pasang SCR (T1,T4 dan T2,T3) pada waktu saat bersamaan sehingga penyearah satu fase terkendali penuh dapat bekerja. Gambar 5. akan menunjukan rangkaian penyearah satu fase jembatan terkontrol penuh.

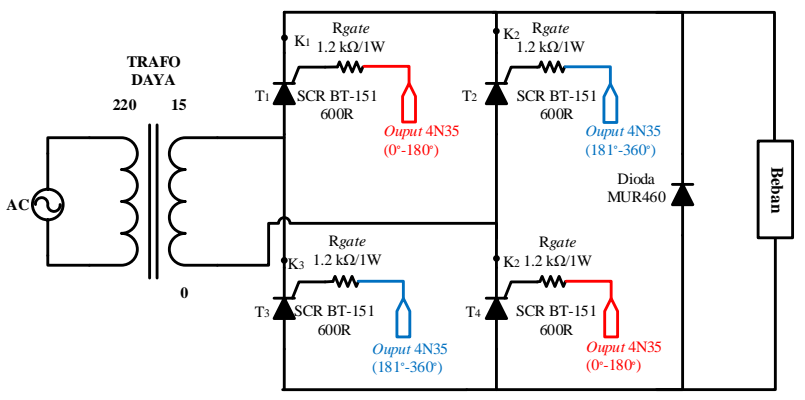

Gambar 5. Rangkaian Penyearah Satu Fase Jembatan Terkontrol Penuh

Untuk melindungi rangkaian penyearah dari arus sisa pada beban induktif dapat memasang sebuah dioda freewheeling yang terpasang paralel dengan rangkaian penyearah. Dioda freewheeling digunakan sebagai perlindungan rangkaian penyearah terhadap adanya arus sisa dari beban induktif[9]. Ketika suplai tegangan pada rangkaian daya dimatikan maka pada beban induktif masih terdapat tegangan pada belitan sebesar $L \frac{d i}{d t}$, sehingga arus sisa akan mengalir ke rangkaian penyearah, jika komponen rangkaian penyearah tidak mampu menahan arus sisa maka akan terjadi kerusakan pada komponen rangkaian penyearah. Pemasangan dioda freewheeling akan mengakibatkan arus sisa yang mengalir dari beban induktif hanya akan mengalir pada sisi dioda freewheeling saja sehingga tidak ada arus sisa yang mengalir menuju rangkaian daya.

\subsection{Penentuan Motor Dan Berat Beban Yang Digunakan}

Untuk sistem hoist pada Prototype Overhead Crane memerlukan sistem lock pada gear agar saat tak bertegangan motor tidak berubah posisi atau tergelincir. Prototype overhead crane mode hoist digerakan oleh motor arus searah tipe CSD80A1-A dengan spesifikasi sebagai berikut:

Tabel 1. Spesifikasi motor arus searah[10]

\begin{tabular}{lllll}
\hline Tipe & $\begin{array}{l}\text { Torsi } \\
(\text { N.m) }\end{array}$ & $\begin{array}{l}\text { Kecepatan } \\
(\text { Rpm) }\end{array}$ & $\begin{array}{l}\mathbf{V}_{\text {rating }} \\
(\mathbf{V})\end{array}$ & $\begin{array}{l}I_{\text {no load }} \\
(\mathbf{A})\end{array}$ \\
\hline CSD80A1-A & 3 & $\geq 90$ & 12 & $\leq 1.5$ \\
\hline
\end{tabular}

Pada Tabel 1. Menunjukkan spesifikasi motor arus searah yang digunakan pada Prototype Overhead Crane mode hoist, dengan parameter tersebut. Untuk mengetahui berat 
beban maksimal yang diangkat oleh motor dapat menggunakan Persamaan (1).

Panjang jari-jari gear motor adalah $2.5 \mathrm{~cm}$, dan torsi pada Tabel 1. adalah $3 \mathrm{Nm}$, maka diperoleh[2]:

$$
\begin{aligned}
& \tau=\mathrm{F} . \mathrm{R} \\
& \mathrm{F}=\frac{3}{0.025} \\
& \mathrm{~F}=120 N
\end{aligned}
$$

Gaya beban yang diperoleh dari Persamaan (1) adalah $120 \mathrm{~N}$, Persamaan

$$
\begin{aligned}
& \mathrm{F}=\mathrm{m} \cdot \mathrm{g} \\
& \mathrm{m}=\frac{\mathrm{F}}{\mathrm{g}} \\
& \mathrm{m}=\frac{120 \mathrm{~N}}{9,8 \mathrm{~m} / \mathrm{s} 2} \\
& \mathrm{~m}=12,24 \mathrm{~kg}
\end{aligned}
$$

\section{Dimana :}

$$
\begin{array}{ll}
\tau & =\text { Torsi }(\mathrm{Nm}) \\
\mathrm{F} & =\text { Gaya }(\mathrm{N}) \\
\mathrm{R} & =\text { Panjang jari-jari gear motor }(\mathrm{m}) \\
\mathrm{m} & =\text { Massa }(\mathrm{kg}) \\
\mathrm{g} & =\text { Percepatan gravitasi bumi }\left(9,8 \mathrm{~m} / \mathrm{s}^{2}\right)
\end{array}
$$

Dari perhitungan pada Persamaan (1) dan (2), maka dapat diketahui berat maksimum yang dapat diangkat motor arus searah CSD80A1-A adalah 12,24 kg.

\section{Hasil dan Analisa}

\subsection{Pengujian Sumber Tegangan AC Satu Fase}

Pengujian yang pertama dilakukan adalah mengukur nilai sumber tegangan jala-jala PLN satu fase 220 volt yang diturunkan tegangannya menjadi 15 volt menggunakan trafo. Bentuk dan besarnya tegangan dapat dilihat pada Gambar 6. sebagai berikut:

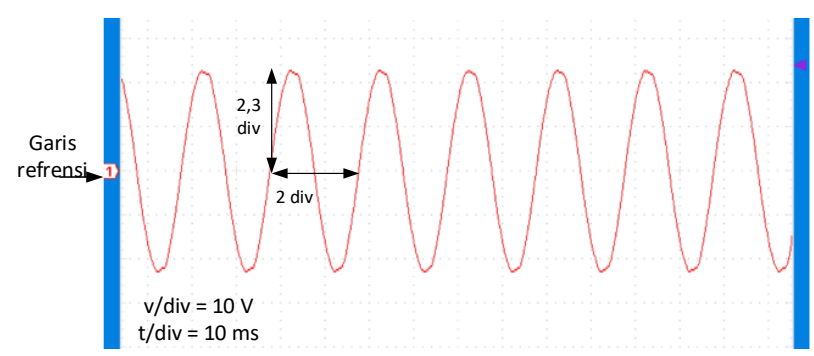

\section{Gambar 6. Gelombang keluaran sumber tegangan}

Trafo digunakan untuk mensuplai rangkaian daya. Pengukuran tegangan pada trafo menggunakan osiloskop. Hasil pengukuran tegangan fase-netral pada sumber satu fase menunjukkan tegangan puncak sebesar 2,1 div, maka dapat dihitung tegangan puncaknya sebesar:

$\mathrm{Vp}=2,3 \mathrm{div} \times 10 \mathrm{v} / \mathrm{div}=23 \mathrm{volt}$

Maka tegangan rata-ratanya adalah:

$\mathrm{Vrms}=\mathrm{Vp} / \sqrt{ } 2$

Vrms $=23 / \sqrt{ } 2=16,2$ volt

Dengan menggunakan Persamaan (3) dapat diperoleh nilai tegangan efektif yaitu sebesar 16,2 volt. Sumber tegangan ini akan digunakan sebagai suplai rangkaian daya dan sebagai tegangan sinkronasi pada IC TCA 785.

\subsection{Pengujian Sumber Tegangan Searah 12 Volt}

Pada pengujian ini, data diambil dari nilai keluaran tegangan searah pada rangkaian regulator tegangan IC LM7812 terhadap ground. Regulator tegangan ini digunakan sebagai suplai rangkaian kontrol IC TCA 785 dan optocoupler 4N35. Gambar 7. akan menunjukkan gelombang keluaran tegangan dari regulator DC 12 Volt.

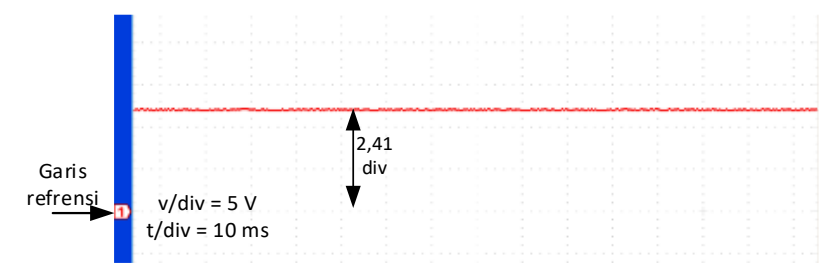

Gambar 7. Gelombang keluaran sumber tegangan searah 12 volt

Gambar 7. menunjukkan besar tegangan keluaran regulator sebesar 2,41 div vertikal sehingga dengan perhitungan didapat nilai tegangan keluaran sesungguhnya sebagai berikut:

$\mathrm{V}_{\mathrm{DC}}=2,41 \mathrm{div} \times 5 \mathrm{~V} / \mathrm{div}=12,05 \mathrm{Volt}$

Seharusnya, nilai tegangan keluaran dari rangkaian sumber tegangan adalah bernilai tepat $12 \mathrm{~V}_{\mathrm{DC}}$ namun pada pengukuran didapatkan nilai $12,05 \mathrm{~V}_{\mathrm{DC}}$. Perbedaan nilai pengukuran dengan spesifikasi disebabkan toleransi LM7812 sebesar $\pm 5 \%[11]$.

\subsection{Pengujian Keluaran Pemicuan IC TCA 785}

Sinyal pemicuan thyristor dihasilkan dari IC TCA 785 . Terdapat 2 sinyal keluaran pada TCA 785 , yaitu pada pin 14 dan pin 15 . Pin 14 merupakan sinyal pemicuan untuk sudut $181^{\circ}$ sampai $360^{\circ}$. Sedangkan pin 15 menghasilkan sinyal pemicuan untuk sudut $0^{\circ}$ sampai dengan $180^{\circ}$. Pembentukan sinyal keluaran IC TCA 785, terdapat beberapa elemen penting, yaitu tegangan sinkronasi, tegangan ramp (gigi gergaji) dan tegangan kontrol. Perpotongan dari tegangan $\operatorname{ramp}\left(\mathrm{V}_{10}\right)$ dan tegangan kontrol $\left(\mathrm{V}_{11}\right)$ akan membentuk sinyal pemicuan yang dapat 
diatur dengan merubah nilai variabel resistor[12]. Gambar 8. merupakan gelombang keluaran sinyal pemicuan dari rangkaian kontrol pin 14 dan 15.

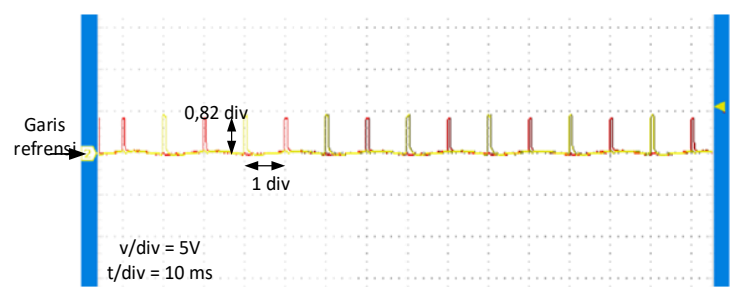

Gambar 8. Gelombang keluaran pemicuan IC TCA 785

Gambar 8. menunjukkan tinggi dan jarak keluaran dari pin 14 dan 15 yang identik dengan tinggi 0,82 div dan jarak kedua keluaran pemicuan 1 div. Nilai yang didapat dari gelombang keluaran IC TCA 785 adalah:

$V=0,82 \mathrm{div} \times 5 \mathrm{v} / \mathrm{div}=4,2$ volt

$t=1 \mathrm{div} \times 10 \mathrm{~ms} / \mathrm{div}=10 \mathrm{~ms}$

Hasil perhitungan menunjukkan tegangan sinyal pemicuan memiliki nilai 4,2 volt. Nilai jarak pemicuan pin 14 dan 15 adalah setengah dari periode tegangan gergaji yaitu $20 \mathrm{~ms}$. Jika diubah dalam sudut dapat menggunakan Persamaan (4) yaitu:

$\alpha=\frac{t}{T} \times 360^{\circ}$

Dengan Persamaan (4) didapat nilai sebesar $180^{\circ}$. Nilai ini sudah sesuai dengan datasheet IC TCA 785 dimana jarak antara keluaran pin 14 dan 15 sebesar $180^{\circ}[5]$.

\subsection{Pengujian Keluaran Isolator Pulsa 4N35}

Gambar 9. Akan menunjukkan gelombang keluaran dari isolator pulsa $4 \mathrm{~N} 35$.

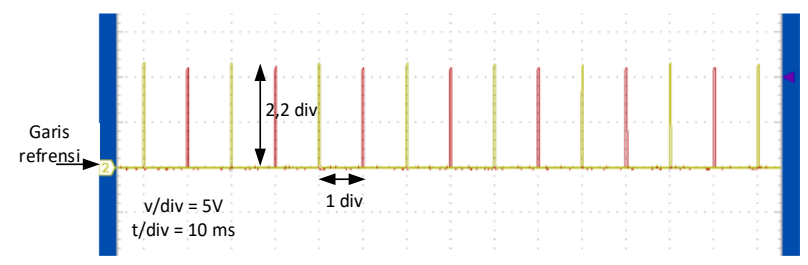

Gambar 9. Gelombang keluaran isolator pulsa 4N35

Keluaran dari isolator pulsa selanjutnya akan digunakan untuk memicu SCR (thyristor) pada rangkaian daya. Hasil pengujian gelombang pemicuan pada Gambar 9 menunjukkan dengan tinggi 2,2 div, dan lebar 1 div. Nilai yang didapat dari gelombang keluaran isolator pulsa 4N35 adalah:

$\mathrm{V}=2,2 \mathrm{div} \times 5 \mathrm{v} / \mathrm{div}=11 \mathrm{volt}$

$t=1 \mathrm{div} \times 10 \mathrm{~ms} / \mathrm{div}=10 \mathrm{~ms}$
Pada rangkaian penyearah satu fase terkontrol penuh ini dibutuhkan 4 buah isolator pulsa dimana masing-masing isolator pulsa mendapat masukan dari rangkaian kontrol IC TCA 785 .

\subsection{Pengujian Rangkaian Penyearah Satu Fase Jembatan Terkontrol Penuh \\ 3.5.1. Pengujian Penyearah Satu Fase Terkontrol Penuh Dengan Beban R dan R-L}

Nilai resistansi yang digunakan pada pengujian ini sebesar $6 \Omega$ dan $20 \Omega$, nilai ini dipilih karena sebagai representasi motor arus searah magnet permanen, nilai tersebut didapat dari metode inject $d c$ terhadap motor pada kondisi berbeban dan tanpa beban. Nilai induktansi yang dipilih adalah $1 \mathrm{mH}$, nilai ini diperoleh dari pengukuran induktansi motor menggunakan LCR meter.

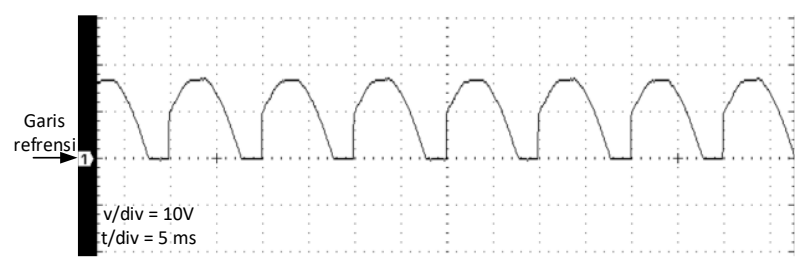

Gambar 10. Bentuk gelombang tegangan keluaran beban $\boldsymbol{R}$ $6 \Omega$ pada $\alpha=50^{\circ}$

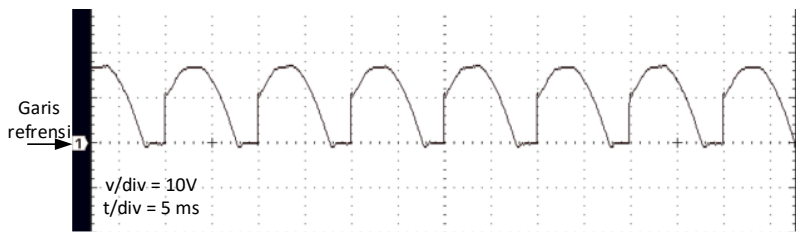

Gambar 11. Bentuk gelombang tegangan keluaran beban $\boldsymbol{R}$ $L 6 \Omega-1 \mathrm{mH}$ pada $\alpha=50^{\circ}$

Gambar 10. dan Gambar 11. menunjukkan bentuk gelombang tegangan keluaran beban $R 6 \Omega$ dan $R-L 6 \Omega$ $1 \mathrm{mH}$ pada sudut pemicuan $(\alpha)$ sebesar $50^{\circ}$. Bentuk gelombang keluaran konverter dipengaruhi oleh besarnya sudut picu penggeser fase oleh IC TCA 785. Semakin besar nilai sudut pemicuan maka nilai tegangan yang dihasilkan semakin kecil, hal ini disebabkan karena luasan gelombang semakin mengecil[13]. Hasil pengujian tegangan keluaran dengan variasi sudut pemicuan pada beban $R$ dan $R$ - $L$ akan disajikan pada Tabel 2. berikut ini:

Tabel 2. Hasil pengujian tegangan dan arus keluaran variasi beban $R$ dan $R-L$ dengan sudut picu $30^{\circ}-175^{\circ}$

\begin{tabular}{|c|c|c|c|c|c|c|c|c|}
\hline \multirow[t]{2}{*}{$\alpha$} & \multicolumn{2}{|c|}{$R 20 \Omega$} & \multicolumn{2}{|c|}{$R 6 \Omega$} & \multicolumn{2}{|c|}{$\begin{array}{c}R-L 20 \Omega- \\
1 \mathrm{mH}\end{array}$} & \multicolumn{2}{|c|}{$\begin{array}{c}R-L 6 \Omega= \\
1 \mathrm{mH}\end{array}$} \\
\hline & $V_{\text {out }}(\mathrm{V})$ & lout (A) & $V_{\text {out }}(\mathrm{V})$ & lout (A) & $V_{\text {out }}(\mathrm{V})$ & lout (A) & $V_{\text {out }}(\mathrm{V})$ & lout (A) \\
\hline $30^{\circ}$ & 12,56 & 0,62 & 10,74 & 1,85 & 12,54 & 0,61 & 10,78 & 1,82 \\
\hline $50^{\circ}$ & 11,53 & 0,54 & 9,92 & 1,65 & 11,53 & 0,55 & 9,87 & 1,64 \\
\hline $90^{\circ}$ & 7,7 & 0,38 & 6,56 & 1,12 & 7,627 & 0,38 & 6,53 & 1,09 \\
\hline $120^{\circ}$ & 5,11 & 0,25 & 4,38 & 0,8 & 5,14 & 0,26 & 4,37 & 0,75 \\
\hline $150^{\circ}$ & 2,26 & 0,15 & 1,9 & 0,37 & 2,264 & 0,14 & 1,93 & 0,36 \\
\hline
\end{tabular}




\begin{tabular}{lllllllll}
\hline $175^{\circ}$ & 1,195 & 0,08 & 1,03 & 0,2 & 1,214 & 0,08 & 1,013 & 0,19 \\
\hline
\end{tabular}

Tabel 2. menunjukkan hubungan antara sudut pemicuan dengan tegangan dan arus keluaran pada pembebanan $R$ dan $R$ - $L$ sudut picu $30^{\circ}-175^{\circ}$. Tabel 2 . menunjukkan bahwa hasil pengujian sudah sesuai teori dan karakteristik penyearah satu fase jembatan terkontrol penuh yaitu nilai sudut pemicuan $(\alpha)$ berbanding terbalik dengan nilai tegangan keluaran[14]. Nilai tegangan dan arus pada $R$ lebih besar daripada $R-L$, namun perbedaan nilai beban $R$ dan $R$ - $L$ tidak terpaut jauh dikarenakan nilai induktansi yang kecil.

\subsubsection{Pengujian Penyerah Terkontrol Terhadap Motor Arus Searah Pada Prototype Overhead Crane Dengan Pembebanan Dan Tanpa Pembebanan}

Pengujian ini dilakukan untuk mengetahui tegangan dan arus keluaran rangkaian penyearah terkontrol terhadap motor CSD80A1-A mode hoisting pada Prototype Overhead Crane dengan nilai sudut pemicuan $30^{\circ}-90^{\circ}$. Gelombang keluaran tegangan akan diberikan pada Gambar 12.

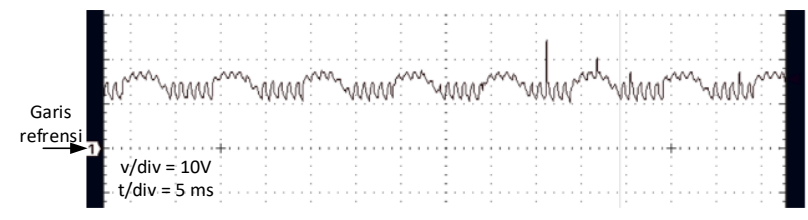

Gambar 12. Gelombang tegangan keluaran tanpa pembebanan mode forward dengan $\alpha=50^{\circ}$

Mode hoisting memiliki gerakan forward (naik) dan reverse (turun), saat kondisi tersebut motor diberikan variasi pembebanan dan tanpa pembebanan. Pada tugas akhir ini teradapat 3 variasi pembebanan yaitu 5, 10, dan 13 kilogram. Pemilihan beban diperoleh dari perhitungan beban maksimum pada Persamaan (2).

Tabel 3. Hasil pengujian tegangan dan arus keluaran pada motor arus searah mode forward dengan sudut picu $30^{\circ}-\mathbf{9 0}^{\circ}$

\begin{tabular}{|c|c|c|c|c|c|c|c|c|}
\hline \multirow{3}{*}{$a$} & \multicolumn{8}{|c|}{ Pembebanan mode forward } \\
\hline & \multicolumn{2}{|c|}{ Tanpa Beban } & \multicolumn{2}{|c|}{$5 \mathrm{Kg}$} & \multicolumn{2}{|c|}{$10 \mathrm{Kg}$} & \multicolumn{2}{|c|}{$13 \mathrm{Kg}$} \\
\hline & $V_{\text {out }}(\mathrm{V})$ & lout (A) & $V_{\text {out }}(\mathrm{V})$ & lout (A) & $V_{\text {out }}(\mathrm{V})$ & lout (A) & $V_{\text {out }}(\mathrm{V})$ & lout (A) \\
\hline $30^{\circ}$ & 14,67 & 1,23 & 13,16 & 1,76 & 11,8 & 2,59 & 11,02 & 2,94 \\
\hline $50^{\circ}$ & 14,52 & 1,15 & 12,91 & 1,6 & 11,8 & 2,02 & 10,89 & 2,65 \\
\hline $90^{\circ}$ & 12,7 & 1,1 & 11,1 & 1,6 & 9,56 & 1,98 & 6,5 & 2,2 \\
\hline
\end{tabular}

Tabel 4. Hasil pengujian tegangan dan arus keluaran pada motor arus searah mode reverse dengan sudut picu $30^{\circ}-\mathbf{9 0}^{\circ}$

\begin{tabular}{|c|c|c|c|c|c|c|c|}
\hline \multirow{3}{*}{$\alpha$} & \multicolumn{7}{|c|}{ Pembebanan mode reverse } \\
\hline & \multicolumn{2}{|c|}{$\begin{array}{l}\text { Tanpa } \\
\text { Beban }\end{array}$} & \multicolumn{2}{|c|}{$5 \mathrm{Kg}$} & \multicolumn{2}{|c|}{$10 \mathrm{Kg}$} & $13 \mathrm{Kg}$ \\
\hline & $V_{\text {out }}(\mathrm{V})$ & $I_{\text {out }}(\mathrm{A})$ & $V_{\text {out }}(\mathrm{V})$ & $I_{\text {out }}(\mathrm{A})$ & $V_{\text {out }}(\mathrm{V})$ & $I_{\text {out }}(\mathrm{A})$ & $V_{\text {out }}(\mathrm{V}) \quad l_{\text {out }}(\mathrm{A})$ \\
\hline $30^{\circ}$ & 15,18 & 1,08 & 15,3 & 1,03 & 15,32 & 0,94 & $\begin{array}{ll}15,4 & 0,92\end{array}$ \\
\hline $50^{\circ}$ & 14,85 & 1 & 14,8 & 0,95 & 15,24 & 0,92 & 15,56 \\
\hline
\end{tabular}

\begin{tabular}{lllllllll}
\hline $90^{\circ}$ & 13,4 & 1 & 14 & 0,96 & 14.8 & 0,86 & 15,2 & 0,78 \\
\hline
\end{tabular}

Tabel 3. dan Tabel 4. menunjukkan bahwa hubungan sudut picu dengan tegangan dan arus keluaran adalah berbanding terbalik. Semakin besar sudut pemicuan yang diberikan maka semakin kecil nilai tegangan dan arus yang dihasilkan[15]. Perhitungan nilai torsi pada motor dapat dilakukan dengan Persamaan (5)[2].

$\tau=\frac{P \times 9,55}{n}$

Keterangan:

$P=$ Daya arus searah (watt)

$n=$ Kecepatan motor (rpm)

Hasil perhitungan torsi pada rangkaian penyearah satu fase terkontrol penuh pada motor arus searah Prototype Overhead Crane mode hoisting dengan variasi pembebanan ditunjukkan pada Tabel 5.

Tabel 5. Hasil perhitungan torsi dengan sudut picu $30^{\circ}-90^{\circ}$

\begin{tabular}{|c|c|c|c|c|c|c|c|c|}
\hline \multirow[b]{2}{*}{$a$} & \multicolumn{4}{|c|}{ Forward } & \multicolumn{4}{|c|}{ Reverse } \\
\hline & $\begin{array}{c}\text { Tanpa } \\
\text { Beban } \\
\tau(\mathrm{Nm})\end{array}$ & $\begin{array}{c}5 \\
k g \\
T(\mathrm{Nm})\end{array}$ & $\begin{array}{r}10 \\
\mathrm{~kg} \\
\tau(\mathrm{Nm})\end{array}$ & $\begin{array}{r}13 \mathrm{~kg} \\
\tau(\mathrm{Nm})\end{array}$ & $\begin{array}{c}\text { Tanpa } \\
\text { Beban } \\
\tau(\mathrm{Nm})\end{array}$ & $\begin{array}{r}5 \mathrm{~kg} \\
T(\mathrm{Nm})\end{array}$ & $\begin{array}{r}10 \\
\mathrm{~kg} \\
\Gamma(\mathrm{Nm})\end{array}$ & $\begin{array}{r}13 \\
\mathrm{~kg} \\
r(\mathrm{Nm})\end{array}$ \\
\hline $30^{\circ}$ & 1,29 & 2,35 & 3,47 & 4,07 & 1,16 & 1,11 & 1,00 & 0,96 \\
\hline $50 \circ$ & 1,22 & 2,19 & 2,92 & 3,72 & 1,09 & 1,01 & 0,98 & 0,88 \\
\hline 900 & 1,16 & 1,93 & 2,66 & 3,33 & 1,07 & 1,00 & 0,94 & 0,85 \\
\hline
\end{tabular}

Tabel 5. menunjukkan bahwa hubungan sudut picu dengan torsi adalah berbanding terbalik. Semakin besar sudut pemicuan yang diberikan maka semakin kecil nilai torsi yang dihasilkan. Untuk mempermudah analisis maka Tabel 5. akan ditampilkan dalam grafik pada Gambar 13.

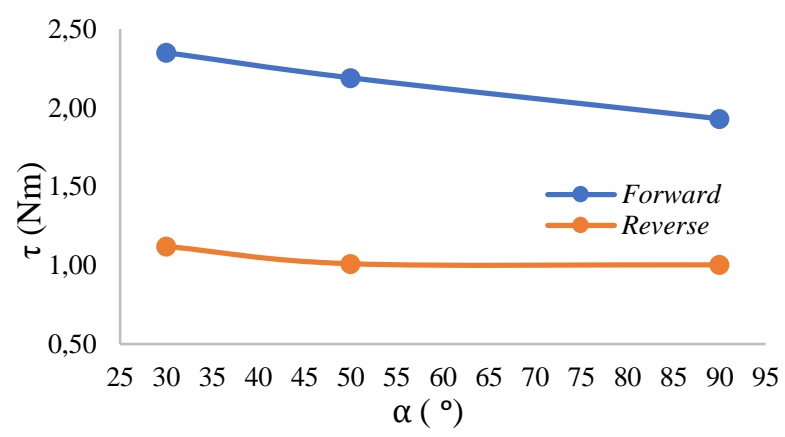

Gambar 13. Hubungan antara torsi dengan berat pembebanan pada $\alpha=30^{\circ}$

Gambar 13. Menunjukkan pada mode forward dan reverse hubungan torsi terhadap sudut pemicuan adalah berbanding terbalik. Nilai torsi semakin bertambah seiring berkurangnya sudut pemicuan karena daya yang dihasilkan semakin kecil. Mode forward memiliki resultan gaya yang lebih besar daripada mode reverse (dengan variasi pembebanan yang sama). Berdasarkan persamaan (1) yaitu 
nilai gaya berbanding lurus dengan torsi, sehingga pada pemebebanan yang sama nilai torsi pada mode forward lebih besar.

Tabel 6. Hasil pengujian torsi dan kecepatan dengan sudut picu $30^{\circ}-90^{\circ}$ mode forward

\begin{tabular}{ccccccc}
\hline $\begin{array}{c}\text { Pembebanan } \\
\text { (kg) }\end{array}$ & \multicolumn{2}{c}{$30^{\circ}$} & \multicolumn{2}{c}{ Sudut picu } & \multicolumn{2}{c}{$\mathbf{5 0}^{\circ}$} \\
& $\boldsymbol{n}(\mathbf{r p m})$ & $\boldsymbol{\tau}(\mathbf{N m})$ & $\boldsymbol{n}(\mathbf{r p m})$ & $\boldsymbol{\tau}(\mathbf{N m})$ & $\boldsymbol{n}(\mathbf{r p m})$ & $\boldsymbol{\tau}(\mathbf{N m})$ \\
\hline $\begin{array}{c}\text { Tanpa } \\
\text { pembebanan }\end{array}$ & 134 & 1,29 & 131 & 1,22 & 115 & 1,16 \\
$5 \mathrm{~kg}$ & 94 & 2,35 & 90 & 2,19 & 88 & 1,93 \\
$10 \mathrm{~kg}$ & 84 & 3,47 & 78 & 2,92 & 68 & 2,66 \\
$13 \mathrm{~kg}$ & 76 & 4,07 & 74 & 3,72 & 41 & 3,33 \\
\hline
\end{tabular}

Dari Tabel 6. dapat diperoleh grafik hubungan kecepatan dan torsi yang akan ditampilkan pada Gambar 14 .

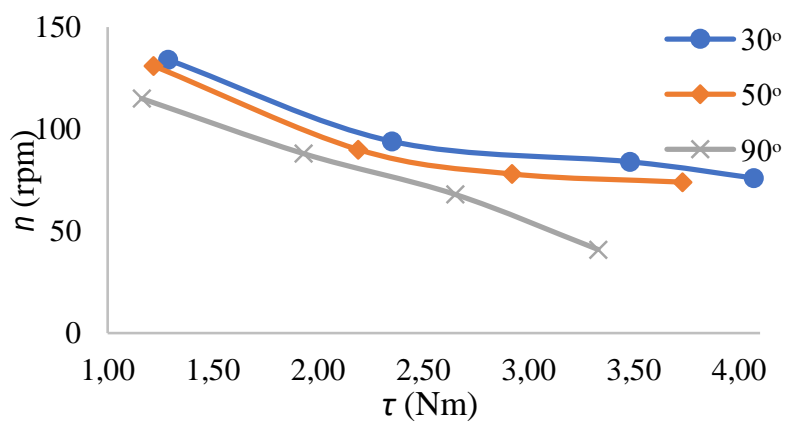

Gambar 14. Hubungan antara torsi dengan kecepatan pada pada mode forward

Pada grafik Gambar 14. menunjukkan hubungan antara kecepatan dan torsi adalah berbanding terbalik dengan sudut pemicuan yang sama yaitu $30^{\circ}$. Berdasarkan Persamaan (5), dimana nilai kecepatan berkurang maka nilai torsi akan bertambah dengan asumsi $P$ (watt) tetap. Hal ini sudah sesuai dengan teori yaitu hubungan antara torsi dan kecepatan adalah berbanding terbalik[2].

\subsection{Perbandingan Daya Masuk dan Daya Keluar Pada Rangkaian Daya}

Nilai perbandingan ini didapat dengan membandingkan daya masukan rangkaian daya dengan daya keluaran rangkaian daya pada motor arus searah Prototype Overhead Crane mode hoisting. Hasil perhitungan efisiensi pada rangkaian penyearah satu fase terkontrol penuh pada motor arus searah Prototype Overhead Crane mode hoisting dengan variasi pembebanan ditunjukkan pada Tabel 7.

Tabel 7. Efisiensi penyearah satu fase terkontrol penuh terhadap motor arus searah

$\alpha \quad \eta$ Forward $\quad \eta$ Reverse

\begin{tabular}{|c|c|c|c|c|c|c|c|c|}
\hline (o) & $\begin{array}{l}\text { Tanpa } \\
\text { Beban }\end{array}$ & $\begin{array}{c}5 \\
\mathrm{Kg} \\
\end{array}$ & $\begin{array}{r}10 \\
\mathrm{Kg}\end{array}$ & $\begin{array}{r}13 \\
\mathrm{Kg} \\
\end{array}$ & $\begin{array}{l}\text { Tanpa } \\
\text { Beban }\end{array}$ & $\begin{array}{c}5 \\
\mathrm{Kg} \\
\end{array}$ & $\begin{array}{l}10 \\
\mathrm{Kg}\end{array}$ & $\begin{array}{l}13 \\
\mathrm{Kg}\end{array}$ \\
\hline 30 & $88 \%$ & $89 \%$ & $87 \%$ & $80 \%$ & $89 \%$ & $89 \%$ & $94 \%$ & $94 \%$ \\
\hline 50 & $82 \%$ & $75 \%$ & $73 \%$ & $72 \%$ & $80 \%$ & $80 \%$ & $89 \%$ & $88 \%$ \\
\hline 90 & $70 \%$ & $72 \%$ & $65 \%$ & $42 \%$ & $74 \%$ & $78 \%$ & $83 \%$ & $84 \%$ \\
\hline
\end{tabular}

Data pada Tabel 7. dapat ditampilkan dalam bentuk grafik pada Gambar 15. berikut:

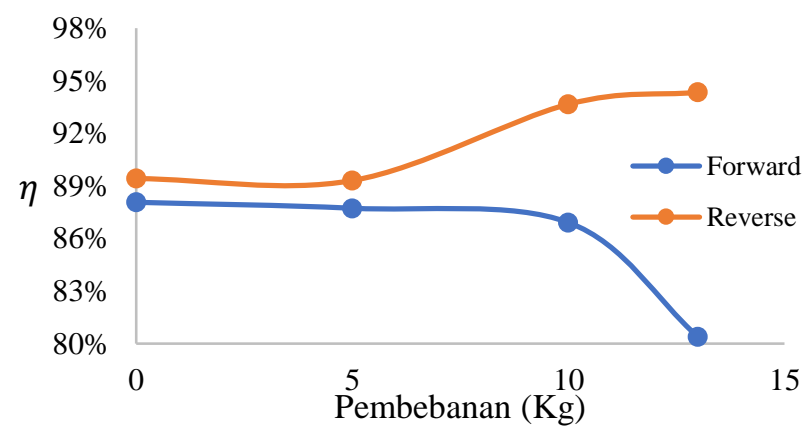

Gambar 15. Hubungan efisiensi dan pembebanan pada sudut pemicuan $\alpha=30^{\circ}$

Gambar 15. menunjukkan nilai efisiensi pada catu daya motor arus searah Prototype Overhead Crane mode hoisting. Hasil pengujian menunjukkan sudut picu berbanding terbalik terhadap perbandingan yang dihasilkan. Semakin besar sudut picu diikuti dengan turunya nilai efisiensi. Pada mode forward nilai efisiensi lebih kecil dari mode reverse pada variasi sudut picu dan pembebanan yang sama.

\section{Kesimpulan}

Penyearah terkontrol dengan topologi penyearah satu fase jembatan terkontrol penuh berhasil dibuat sebagai catu daya untuk beban $R, R-L$, dan motor arus searah pada Prototype Overhead Crane mode hoisting. Penyearah terkontrol bekerja dengan baik pada saat diberikan sudut picu $(\alpha) 30^{\circ}-175^{\circ}$ pada beban $R \& R-L$ dan sudut picu $(\alpha)$ $30^{\circ}-90^{\circ}$ pada motor arus searah mode hoisting. Hubungan sudut picu thyristor terhadap nilai keluaran tegangan dan arus searah yang berbanding terbalik, semakin besar sudut pemicuan maka tegangan dan arus keluaran semakin kecil. Pengujian pada plant mode forward (naik) dengan variasi pembebanan dengan sudut picu $(\alpha)$ thyristor $30^{\circ}-90^{\circ}$ didapatkan hasil hubungan antara variasi pembebanan terhadap kecepatan putar (rpm) adalah berbanding terbalik, namun pada mode reverse (turun) dengan parameter percobaan yang sama didapatkan hasil hubungan antara variasi pembebanan terhadap kecepatan putar (rpm) adalah berbanding lurus. Perbedaan tersebut disebabkan torsi yang dibutuhkan untuk mode forward lebih besar daripada mode reverse karena nilai torsi berbanding terbalik dengan kecepatan putar motor yang dihasilkan. Pengujian menunjukan bahwa sudut pemicuan berbanding terbalik dengan efisiensi. Hasil pengujian menunjukan efisiensi paling baik pada mode forward bernilai $89 \%$ dengan 
variasi tanpa pembebanan dan pembebanan $5 \mathrm{~kg}$. Pada mode reverse variasi pembebanan $10 \mathrm{~kg}$ dan $13 \mathrm{~kg}$ bernilai $94 \%$. Keduanya diperoleh pada saat sudut picu yang sama yaitu $30^{\circ}$. Untuk penelitian lebih lanjut, dapat dikembangkan kontrol pemicuan dengan menggunakan mikrokontroler.

\section{Referensi}

[1] Ray Siddhartha, Introduction to Materials Handling New Delhi: New Age International, 2008.

[2] T. Wildi, Electrical Machines, Drives, and Power System, Fifth. New Jersey: Prentice Hall, 2002.

[3] R. K. Rajput, Electrical Machines Fourth Edition. New Delhi: Laxmi publications, 2007.

[4] M. H. Rashid, POWER ELECTRONICS Academic Press Series in Engineering. California: Academic Press, 2001.

[5] S. Semiconductor, "Datasheet TCA 785." pp. 1-16, 1994.

[6] W. A. Bianto, M. Facta, and T. Andromeda, "Softstarting Pada Motor Induksi 3 Phasa Menggunakan Ic Tca 785," Transient, vol. 1, no. 1, pp. 1-7, 2006.

[7] E. Setiawan, F. Mochammad, and A. Nugroho, "Penggunaan Konverter Jenis Buck Dengan Pemutus Tegangan Otomatis Untuk Pengisi Akumulator," Transient, vol. 4, no. 1, pp. 51-57, 2015.
[8] V. Semiconductors, "Datasheet Optocoupler 4N35." pp. 153-159, 2010.

[9] N. Mohan, Power Electronics Converters, Applications, and Design, Second. New York: JOHN WILEY \& SONS, INC., 1995.

[10] N. L. ELECTRICAL, "Datasheet Motor CSD80A1-A," no. Nov. pp. 1-11, 2011.

[11] G. Description, V. Range, and C. Diagrams, "LM78XX Series Voltage Regulators LM78XX Series Voltage Regulators," no. February, pp. 1-6, 1995.

[12] M. R. Fajar, T. Andromeda, and M. Facta, "IMPLEMENTASI IC TCA 785 DENGAN TRANSFORMATOR PENGGESER FASE PADA PENYEARAH TIGA FASE JEMBATAN TERKONTROL PENUH," Transient, vol. 6, no. 1, pp. 81-96, 2017.

[13] A. Purnomo, T. Sukmadi, and M. Facta, "Perbandingan Pengaturan kecepatan Motor Induksi Satu Fasa Menggunakan Variac dan Konverter AC-AC Kontrol Sudut Fasa Berbasis IC TCA 785," Transient, vol. 3, no. 4, pp. 595-602, 2014.

[14] M. D. Singh, Power Electronics, Second. New Delhi: Tata McGraw-Hill Publishing Company Limited, 2007.

[15] P. Tawakal, A. Nugroho, and M. Facta, "Penyearah Terkontrol Penggerak Motor Arus Searah Pada Purwarupa Konveyor," Transient, vol. 5, no. 3, pp. 389394, 2016. 